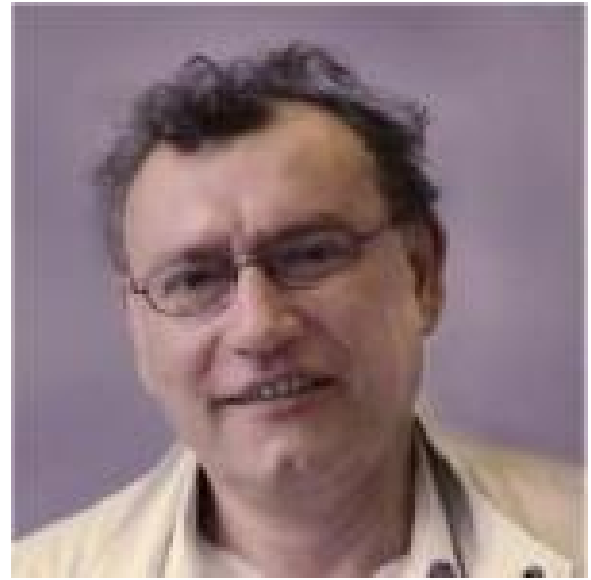

\title{
BARTOLOMÉ LEAL: THE WHITE NEGRITUDE OF ALTERITY
}

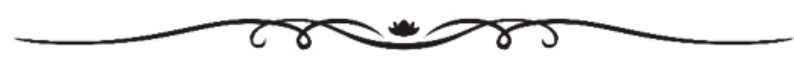

(C) Néstor Ponce, Professor, Université

Rennes 2 / ERIMIT, Rennes, France, nestorponce35@yahoo.fr

Translated into English by John Swift, Max Ubelaker Andrade

\section{Summary}

This article is a study of Blanca de negro (2015), a novel by the Chilean writer Bartolomé Leal. Leal's text plays with the tensions between the crime novel and the ethnological novel, pointing us toward an encounter with the contemporary social characteristics of the capital city of Nairobi alongside, more indirectly, those of the other regions of Kenya. Leal's work is inscribed within a tradition that questions the relationships between cultures from a dynamic and polemic point of view, confronting different ethnicities and nationalities that form part of the African country.

Key words: Bartolomé Leal, crime novel, ethnological novel, alterity, cultures.

The works of Bartolomé Leal (1946) are both multiple and varied. They touch upon several literary fields (essay, chronicle, fiction -novels, short-stories) ${ }^{1}$, including the detective novel. Yet, Leal's creative noir displays a distinctive style; 'a priori', his works fall into a category described by critics as the 'ethnological novel'. As Wilberio Mardones (see Bibliography) points out in the preface to 'Blanca de negro' (2015)2 , the ethnological novel immediately sets into motion an examination of both structure and content problems. It is this position which I propose to explore. It is a question of challenging the ideas collected about 'primitive' populations, about the indigenous populations, and about the tribal strictures in place. In this context, it is necessary to call upon a historical viewpoint, a Rhizomatic viewpoint (Deleuze, Guattari, Glisssant) capable of decoding the effects of colonization, of oppression, of misery, but also of interbreeding and syncretism. This implies the need to deconstruct the authorreader contract the narrator searches for, insofar as to allow the elements of the 
investigation to be transfixed by local culture (Kenya). The signs of cultural identity, of the recognition of alterity, increase in these types of texts; to understand the nature of the crimes and the arguments of the researchers, one must get to know the native people. Who really are they? How do they reflect?

In Hispano-American crime stories there exists a tradition of the indigenous as being 'present'. I myself have spoken paradoxically, in an article published in $2013^{3}$, of 'the story of an absence'. What do I mean? Despite the determining importance of the indigenous population throughout the conquest and colonization initiated at the start of the $15^{\text {th }}$ century, despite the presence today of more than 26 million indigenous people and tens of millions of mixed race people, crime literature is far from integrating them into its stories. The clashing of mentalities marked by the conquest identifies also the perplexity of going against the 'other'. This paradoxical presence of absence expresses a practicing of memory within fiction which impregnates the representation of the indigenous Other, nay of the Other full stop (through the rendering of gender, ethnicity and social class). Human experience, lived, repression, memory.

In the hermeneutic code of the detective story, which displays a rather rigid fictional band of characters (investigator, culprit, victim, suspect - I will return to this point at the end of this piece) and which gives priority to urban spaces, the presence of indigenous people since the appearance of the first generic fictions (1878 in Argentina with Raúl Waleis) is erratic, indeed non-existent. Grouped alongside mixed-race people, immigrants, and women, the indigenous are thought of as the ideal suspects. That said, to find crime texts which accord to the indigenous population, or its culture, a role appropriate to its social importance, one would have to set out on a veritable quest. I refer you to my 2013 study, in which I analyze four fictional crime stories ['El crimen de Ducadelia y otros cuentos del Trío' (1959) by Leonardo Castellani (Argentina); 'Hot Line' (2001) by Luis Sepúlveda (Chile); 'Muertos incómodos' (2005) by Subcomandante Marcos and Paco Ignacio Taibo II (Mexico); and 'X-Teya, u puksi'ik'al koolel, Teya, un corazón de mujer' (2009) by Marisol Ceh Moo (Mexico). This last novel has the distinctive feature of having been presented as a bilingual edition, MayanSpanish, the first part being written completely in Mayan].

“X-T Martine' mix bik'iin ken u tubsej le u k’iinil ka jimij j Emeterio', weenij. Utia'ale' tumeen u jach ts'aamubaj u kalaantej le u nojchil ichil u yalo'ob, le weniko' jun p'éel ba’al jach tun k’aas, le ucha' yáan u mejati' u tia'al u chuunsik u K’aasik tulaakal le ba’alo’obo'ku ye’esiko’ob le yayajóoli tu p'aataj le kimsaj 
uuch ti’le káajo” (p. 9).

“Lo que jamás olvidaría Teya Martín es que el día de la muerte de Emeterio se quedó dormida. Para ella, dedicada íntegramente al cuidado de su hijo mayor, éste fue un desliz que le serviría como punto de referencia cuando sus recuerdos la llevaran por los caminos que marcaron el asesinato de mayor consternación en la región” (p. 197).

Yet, if we refine this as a reflection on the presence of indigenous peoples in crime stories in comparison with Hispano-American literature in general, it should be noted that the central problem concerns the representation of alterity, ever since the first appearance of indigenous people in the 'Journal de bord' (1942) from Christopher Colombus' first voyage. This representation is at odds with itself, if we return to the crime story, to the relation of alterity with the functioning of characters, in a literature where the constructions concerning good and bad, true and false, justice and injustice participate in an active manner in the elaboration of the code of representation. The conflict of virtues takes centre stage, to the extent that the vagueness which surrounds the definition of aforementioned concepts blurs the interpretation of recounted memories. Or still: Where is good? Where is justice? What is true? As soon as the Other shows its face, all of these concepts are returned to a semantic conflict. Placing the indigenous in the role of investigator not only affords them a central role in the diegisis, but above all provokes a semantic vertigo in the configuration of the cast of characters. The Other passes from the role of suspect or culprit to a role inhabiting the common thread of the plot.

The essential element of indigenous presence in these stories is situated at a complete other level. The integration of the indigenous into the central group of characters within crime stories poses a problem, both to research and to the account of investigators' 'primitive' thoughts on the methodology of deduction (or induction). I return to my aforementioned remarks: can indigenous thought be compatible with reason? Can 'barbarism' bring innovative resources to investigation? What is the place of the indigenous Other in an investigation? Max Caisson $^{4}$ (1995) mentioned ethnographic stories, namely texts where the relationship between the Other and reality is discovered. Also, like in some indigenous novels by Rosario Castellanos and José María Arguedas ${ }^{5}$, Ceh Moo, Marcos and Sepúlveda try to filter the viewpoint of the indigenous from the 
interior of their conscience. This perception of the world harks back to the Australian Arthur Upfield (1888-1964), researcher of Napoleon Bonaparte (called Bony: again to show the ironic importance of the name), half-white, halfindigenous, who breaks through the mysteries by calling on his own internal logic to find his way through the universe. The same goes for Tony Hillerman (19252008), creator of two police officers of the Navajo Tribal Police, Joe Leaphorn and Jim Chee (the latter having experience an otherwise anthropologist upbringing).

This introduction allows us to return to 'Blanca de negro'. This novel is the followup to 'Linchamiento de negro' (1994). Both texts take place principally in Nairobi, capital of Kenya - where Leal has himself resided for many years - but also in other regions of the country. The protagonist is a mixed race Kenyan, Thimoteus (Tim) Tutts, who runs the T.T.\&T. (Thimoteus Tutts \& Team detective agency), whose office is located on No. 33 River Road (which becomes a sort of African 221b Baker Street). It is located in a working class area of the city with more than three million inhabitants, considered the most important in East Africa. Tim, a man who possesses a certain amount of culture and who is little vain, is assisted by three other characters: Caroline (Curly) Negatu, secretary, Karima Waweruy, assistant, and Joseph (Joe) Ndege, detective. The four members of the agency are representations of different ethnicities and the text is strewn with cultural and tribal information (physical, language, religion, proverbs, cuisine, architecture et cetera) which equally relates to the whole immigrant community (Hindu, Pakistani, Arab, English et cetera). These ethnic groups and these immigrants, despite sometimes benefiting from a certain commercial success, all know what it is to suffer hardship, whether it be from conquest, slavery, colonization or discrimination. All this information appears in the text, but is measured out slowly and wisely to maintain a breathless plot - there is no place for lampooning or schematic speech here.

The plot of 'Blanca de negro' allows for all of the societal conflicts of Kenya to be put on the table and the role of the international organization present within the country, for example, to defend the ecosystem, and who hire white people whose behaviour often resembles that of colonialists or high class Kenyan civil servants, to be put into question. The novel sets itself out as a traditional detective story. Halley Canary, an American woman born in Chile - and whose name refers to both the canary bird and the travelling comet - works for the OMDE (Organisation Mondiale pour la Défense de l'Ecologie), whose headquarters are located in Nairobi. Going for a walk at the end of the day in the park situated in 
the extremely chic Nairobi Golf Club, a legacy of English colonization and found in the elegant Gigiri neighbourhood - a woman is assaulted and raped by some black mean talking in Swahili (a language of Bantu origin spoken in several African countries, like Kenya, of course, but also Uganda, South Africa, Rwanda and Comoros et cetera). The description of the assault, a scene of terrible violence, is told in a conscientious manner by a narrator who assumes the point of view of the victim with subtlety. The daily violence is miserable and cruel but it nevertheless allows humanity a new lease of life through the attitude of doctors, nurses, and detectives.

Halley Canary, aggrieved by the lack of action from the Police, then decides as a last resort to contact the T.T.\&T. agency. In the meantime, the text offers us a first panoramic view of Kenyan society - the difficulties faced by hospitals, problems with justice, the vanity of white people working for the OMDE (a host of nationalities including Belgians, French, Italians, and Uruguayans). The external structure of the novel is owing to, as I said from the beginning, this importance which is placed upon ethnology. Also, each chapter is marked by territoriality, acting much like a marker of identity, bringing with it the name of a street (River Road), an area (Gigiri), a point in the road (Dagoretti Corner), a region (Mombasa) et cetera. Equally, the end of each chapter finishes off, as a sort of reverse epigraph, with a proverb, a saying or even a 'superstition' of the country (Masai proverbs, p.34; Kikuyu proverbs, p.48, Abaluyin proverb, p.76; Swahili proverb, p.137). This distinctive characteristic proposes a contrast in the linearity of the traditional crime story, and installs a mythical circularity, which calls on a different knowledge, non-Western, but full of resources and of methods of operating as a key to deciphering the mystery.

In the same way, from the point of view of internal structure, the narrator stops offering the minute detail, playing with what Manuel Vázquez Montalbán called the 'dead times' of the story, that is to say the passages in which the author 'abandons' the thread of the plot in order to produce reflections of all kinds (descriptions of landscapes, musical tastes, extracts from the free press, cooking et cetera). Among those present in Bartolomé Leal's novel, I will quote from the beginning of the novel, showing the images of nature and of the Kenyan twilight:

« Es la hora en que los amarillos se transmutan en dorados, los verdes compiten en intensidad y originalidad, los rojos llegan a herir la vista. Cada flor parece esforzarse para mostrar que sus colores son superiores. En los sentidos del 
paseante se imponen primero que nada las mimosas, con sus suaves capullos amarillos y sus fragancias intensas ; luego la vista se recrea en los variados rojos de flamígeros, patas de camello, plumillas, eucaliptos, pimientos y tuliperos de África que, competitivos se esmeran con su variedad cromática, con su repertorio de formas y tamaños, con sus aromas delicados y misteriosos » $^{6}$

The descriptions of towns, of areas, of regions, of architecture equally make up other strong points within the novel. The territoriality also allows the designing of a cultural cartography, unexpected and extremely rich, which shows the diversity and tensions within society. With the transition after English domination (Kenyan independence was declared in 1963) also comes a host of transitional problems, corruption, and the presence of different communities which form an almost mosaic, waiting to crack.

As far as corruption is concerned in the second chapter, colour is definitely made to be public:

« Una Policía tan corrompida que bordeaba lo delincuencial no era ninguna garantía; y menos aún un poder judicial acostumbrado a resolver situaciones sin esforzarse por esclarecer eso que se suele llamar la 'verdad'. Y en buena parte por razones financieras u operativas, hay que reconocerlo: existían jueces $\mathrm{y}$ magistrados honestos... » (Leal, 2014; p. 37).

It is not necessary to abound with other examples surrounding this question, but during a work trip to the incredible Takwa island, the reassuring figure of Police Lieutenant Abubakar appears - a friend of Tim Tutts - who saves a life, at least preventing another rape, by two fishermen on the island. This had been where the American woman's so-called quest for exoticism had led her to.

Yet, if we return to the urban territories, it must be noted that the image portrayed of the capital, Nairobi, is lively and colourful, but always subtle, without ever falling into the trap of eroticizing, perfectly integrating with the transformation of fiction. The characters and their movements - by different modes of transport, a little like the image of travel literature ${ }^{7}$ - follow a path which is in and of itself a journey towards alterity. Points of view are decisive in the construction. To the commentary by the narrators, the point of view of other characters is added, of Halley Canary - certainly more tolerant than 'an elegant Manhattan lady', but 
whose words show the difference, of Tutts himself - who straightaway shows his understanding - 'a hung up mixed race man' in the words of an old fiancée -, from associates to the detective, all from different ethnic origins (Somalian, Masai, mixed race), then the sometimes pedantic point of view of the member of the international organization, the OMDE, for whom the rape victim worked.

Capturing territoriality and identity based on modes of transport equally implies an understanding of the Other's way of living. Accidentally falling into the gutter and plunging into the rank waters, setting sail in a boat captained by two shifty and visibly drugged up youths, boarding a plane whose propellers are put into place at the last moment before take-off, clearly shocks the American, Halley. There resides in her, more than the passion to know the Other, a rather benevolent thirst for gratitude for herself. Either it is the distance between the desire for exoticism - which implies a great superiority ${ }^{8}-$ and the cruel reality. Or it is somewhat like the images painted in France which try to reconstruct a distant and remote world, which can be dreamt of now, but which is coming into sight.

The technique of identification with space - one identifies with certain things when they are part of one's every day or even when they evoke within oneself a buried emotion or feeling - reproduces itself when the question of Lamu island's architecture arises, the island being an old sultanate wet by the greenish waters of the Indian Ocean. The journey through the island's back streets encased by houses made of coral and stone, modelled with abstract decors, signs of Islam on the exterior walls, with large, sculpted wooden doors, is led by Patricia, a Panamanian anthropologist. At this point, the Alterity of rhizome, the discovery of diversity is placed in relation to the principal investigation and allows, in the moments shared during a journey, a way of better understanding the personalities of the characters.

As far as the mixing of cultures goes, with the diversity and the 'street art' which abounds in the many dirty and humid streets of Nairobi, Bartolomé Leal has already offered us a first glimpse into this phenomenon in 'Linchamiento de negro'. The author's argument is developed here:

« El salón de peluquería femenina y el negocio de fotografía estaban anunciados por coloridos murales, hechos en el estilo de muchos otros similares que Halley había disfrutado en Nairobi y diversas ciudad del país, un arte de auténtico estilo ingenuo, dotado por añadidura de un humor incomparable. En esta ocasión vio una serie de bosquejos de intrincados peinados de trencillas, las especialidades de la casa, imaginó, los que eran mostrados por unas bellas cabezas dibujadas con 
mínimos colores y traos fuertes y seguros » (Leal, 2014, p. 39).

This mixing plays a considerable role in the introduction of another type of 'dead time', a syncope that the narrator introduces into the story. Here, it is the cuisine. This can be seen as an homage to the Catalan author Manuel Vázquez Montalbán. His detective stories are filled with meticulously outlined recipes and are accompanied by a list of wines suggested to enhance the dishes' taste. So common are these types of texts from Montalbán that he decided to publish the full collection under the title 'Carvalho's Recipes' - private detective Carvalho being the name of the principal character within his detective stories. As for Tutts' story, we discover the smells, tastes and textures of another cuisine. We experience curry and a mix of other sauces, the meats and fish of Kenya, the cereals - often mixed with maize - and the fragrant rices flavoured with spices which can be found nowhere else. Tutts invites Halley for lunch in order to discuss the case. At the restaurant they are presented with a large variety of meats accompanied by sauces and other typical products. Halley raves over the vegetarian meals and the Thika chicken - a Kenyan-Asian specialty.

Throughout the novel, closed spaces are used in order to highlight the latitude of social differences. We see the muted and luxurious environment, richly decorated with sumptuous gardens - another legacy of colonialism - of the dominant classes, mainly the Whites. Interior spaces which replicate Western tastes, with an added hint of African exoticism. In return, we discover the modesty of the indigenous habitats. This is a contrast which is not presented as a lampooning but rather which is happy to function as a 'display', allowing the receive to come to their own conclusions. The building where Tim's office is situated constitutes another example of these differences. It is dirty and run-down. The agency's nameplate at the entrance to No. 33 is filthy and it should be remembered that the premises are located on River Road, a working class area in the old centre of Nairobi, not far from the cluster of tall business towers, financial agencies and hotels catering for tourists. A comparison with the office of Héctor Beloascarán Shayne, the private detective penned by the Mexcian author Paco Ignacio Taibo II is irresistible. Additionally, Tim shares his floor - just like Héctor - with a group of different businesses: two hairdressers, an Indian ophthalmologist, a lawyer specializing in land disputes, and a photographer. The clientele are the ultimate representation of the working class. During one of her strolls, seeking out exoticism wherever she can find it, Halley comes across the agency's premises 
and is, firstly, rather critical. To her, a detective agency being present in this kind of area makes her laugh. However, in a desperate situation after the rape, and without fully believing in her own decision, she decides to call on Tutts and his team, these 'so-called Kenyan private detectives', for help.

The interior of the premises further strengthens the comparison with Beloascarán Shayne, Taibo II's disabled detective. The internal focalisation, through the character of Halley Canary, refers to a vast space, badly decorated, 'like something straight out of a gangster film'. Intertextuality is, again, present here with Tutts' office being comparable to that of Sam Spade's, in the style of Humphrey Bogart. Intertextuality equally rears its head in relation to the descriptions of characters. In this way, Tutts, a mix of Welsh and Kikuyu, is linked several times to Hercule Poirot and his less than graceful, almost comical, physique brought to life by Agatha Christie. After the first meeting with the American, he plays with his moustache hairs on his upper lip, à la Bogart. Halley, of course, understands the message perfectly and is shocked by the man's pedantry. Later on, Tim does not hesitate in talking about his 'grey cells'. In addition, as we see in both novels, Tutts is an avid reader of the press, allowing him to stay well informed of different facts about the city and to better organize his research and findings. This is a nod to Edgar Allan Poe and to the Knight Dupont, such as we discover in 'Double assassinat dans la rue Morgue'. It's a question of spoof situations being presented as tributes, according to Linda Hutcheon's definition. ${ }^{9}$

Throughout the evolution of the crime story within the 1950s (in parallel with cinema and later on with TV crime dramas), for reasons both literary and social, which I will not expand on here owing to limitations on space, there appeared a new type of protagonist: the team. Following on from this came the duo of teammates, made up of police officers and/or secret service. The private detective (of every type, be it man, woman, gay, lesbian, Jewish et cetera) and, indeed, the detective accompanied by a confidant, of course, continue to exist. In 'Blanca de negro', even though Tutts assumes the principal role, the team which surrounds his is extremely active, participating, discussing, and contributing to finding an explanation for whichever case they may be investigating.

The cultural elements alluded to earlier (ethnic groups, proverbs, languages, architecture, food) create a sense of credibility. Halley's rude comments reinforce this feeling. For example, she talks about Tutts' cleanliness and compares it to the smell of axiles and of Kenyan people's feet, 'of every social class', to the extent that they come to represent different readings of reality and act as a sort of appeal 
to the reader. In the same way, the intertextuality is, naturally, a call to the receiver, weaving a line of complicity, which serves to, little by little, regulate and complete the formation of an author-reader contract. This 'sense of reality' contributes to reinforcing the credibility of the plot and necessitates, to return to our starting point, an interaction between the reader and Alterity.

To finish with the analysis, the discovery of the culprits' identities corresponds to the distinctive traits of the ethnological novel seeing as it returns us to postcolonialism and to the exploitation of black people, undeniably victims of great injustice. Money lies at the centre of this problem and the author calls for a typical solution in his stories. The culprit, a poor man, who received money for committing his crime, must generously spend his money at a bar in town. This corresponds exactly to the behaviour of one of the characters in the Catalan author Andreu Martin's last novel, 'Société noire ${ }^{10}$ (or the Canarian novelist Alexis Ravelo, in La estrategia del pequinés), et facilite le travail des enquêteurs qui finissent par le retrouver. « Claquer » l'argent est une manière de se dénoncer par l'excès. Et l'excès se paie cash. Car dépasser les limites n’est toléré que par ceux qui ont le pouvoir de l'excès: les médias, les footballeurs, les artistes. L'hyperbole apparaît comme une ressource littéraire pour montre les déséquilibres sociaux, car pour être excessif il faut avoir la protection des toutpuissants.

In conclusion, this book by the Chilean Bartolomé Leal skillfully goes back to and takes advantage of the ethnological novel, shown from the title, with both novels containing the word 'noir'. (Linchamiento de negro, Blanca de negro), and incorporates it into the category of the crime story. In doing so, the author calls on his own knowledge of anthropology, sociology, linguistics, but also of the distinctive resources of the crime genre (structure, characters, intertextuality). It is difficult, if not impossible, to talk of a major or a minor, seeing as both types of stories mix together, integrate and merge. In this context, the question of genre and sub-genre rears its head. I propose an egalitarian treatment in discussing Leal's novel and I prefer the term 'ethnological crime novel'.

\footnotetext{
${ }^{1}$ Some of B. Leal's titles: Linchamiento de negro (1994, novel), Morir en La Paz (2003, novel), En el Cusco del rey (2007, novel), Pequeñas muertes negras (2009, short stories), Historias del muñeco vudú (2013, short stories), El arte de la parábola (micro-récits, 2014).

${ }^{2}$ Leal, Bartolomé (2015). Blanca de Negro. Santiago de Chile : Espora.

${ }^{3}$ See Ponce, Néstor (2013). Autochtones et récits policiers en Amérique Hispanique. Amerika, (on line), number
} 
8. Available at: $n^{\circ}$ 8: http://amerika.revues.org/3914).

${ }^{4}$ Caisson, M. (1995). L'Indien, le détective et l'ethnologue. Terrain, (on line), number 25. Available at: http://terrain.revues.org/index2856.html (Accessed 18 ${ }^{\text {th }}$ January 2010. DOI : 10.4000/terrain.2856).

${ }^{5}$ In effect, the critic employs the term 'ethnological novel' in reference to the worls of Arguedas and Castellanos. It is undeniable that their musings on the Indians in the Andes or Chiapas give a great deal of information about the cosmo-visions and cultures of these regions. Leal also defined the 'ethnological novel': "It's a type of narration whereby the topics of ethnicities, indigenous cultures, witchcraft, colonial conflicts, and others, appear at the heart of the work. The arguments, the plotlines, the characters, and the spaces bear witness to these major conflicts which, either explicitly or implicitly, manifest themselves in societies marked by ethnic, cultural and/or religious diversity. (Cit. par Caisson, M. (1995). L'Indien, le détective et l'ethnologue. Terrain, (on line), number 25. Available at: http://terrain.revues.org/index2856.html (Accessed $18^{\text {th }}$ January 2010. DOI : 10.4000/terrain.2856).du-noir.html). I will come back to the term 'exotic'.

${ }^{6}$ The images of nature present in Leal's novel are similar to M. M. Kaye's (1991) descriptions in Muerte en Kenia. Barcelona : Plaza \& Janés.

${ }^{7}$ See Cogez, M. (2014), Partir pour écrire. Figures du voyage. Paris: Honoré Champion.

${ }^{8}$ Staszak, J.-F. Qu'est-ce que l'exotisme, Le Globe, Revue genevoise de géograhie (on line), Tome 148. Avalaible in https://www.unige.ch/sciences-societe/geo/files/4314/4464/7645/Globe2008_Article1_.pdf (Accessed 20 th November 2016).

${ }^{9}$ A Theory of Parody: The Teachings of Twentieth-Century Art Forms, Champaign and Urbana: University of Illinois Press, 2001 (1984). The 2001 edition offers a new introduction which acts as a real update in regards to the concept of parody.

10 Paris, Asphalte, 2016 (translated from the Catalan by Marianne Millon). Original version: Sociedad negra, Barcelona, 2013.

\section{REFERENCES}

Benjamin, W. (2000). Euvres completes. Paris: Seuil.

Caisson, M. (1995). L'Indien, le détective et l'ethnologue. Terrain, (on line), number 25. Available at: http://terrain.revues.org/index2856.html (Accessed 18 ${ }^{\text {th }}$ January 2010. DOI : 10.4000/terrain.2856).

Castellani, L. (1942). Las muertes del Padre Metri. Buenos Aires: CEPA.

Castellani, L. (1959). El crimen de Ducadelia y otros cuentos del trio. Buenos Aires: Doseme.

Ceh Moo, M. (2008). X-Teya, u puksi'ik'al ko’olel. Teya, un corazón de mujer. México Consejo Nacional para la Cultura y las Artes, Letras Indígenas Contemporáneas.

Cogez, M. (2014), Partir pour écrire. Figures du voyage. Paris: Honoré Champion.

Eco, U. (1985). Lecteur in Fabula. Paris: Grasset.

Hamon, Ph. (1984). Texte et idéologie. Paris: Presses Universitaires de France. 
Haycraft, H. (1942). Murder for pleasure: the life and times of detective story. London: Peter Davies.

Hillerman, T. (1991) Dieu qui parle. Paris: Payot-Rivages.

Hutcheon, L. (2001). A Theory or Parody: The Teaching of Twentieth-Century Art Forms, Champaign and Urbana. $2^{\text {nd }}$. edition. Illinois: University of Illinois Press.

Kaye, M. M. (1991). Muerte en Kenya. Barcelona: Plaza \& Janés.

Kracauer, S. (1981). Le roman policier. Un traité philosophique. Paris: Payot.

Leal, B. (2015). Negra de blanco. Santiago de Chile: Espora.

Leal B. (1994). Linchamiento de negro. Santiago de Chile: Linterna Mágica (col. Crónica roja).

Leal, B. (2003). Morir en La Paz. Cochabamba: Umbriel.

Leal, B. (2007). En el Cusco del rey . Cochabamba: Umbriel.

Leal, B (2009). Pequeñas muertes negras. Santiago de Chile: Mosquito comunicaciones.

Leal, B. (2013). Historias del muñeco vudú. Santiago de Chile: Planeta sostenible.

Leal, B. (2014). El arte de la parábola. Santiago de Chile: Plaza de letras.

Leal, B. (2015). El hombre Nuevo. Santiago de Chile. Tambo quemado.

Lits, M. (1993). Le roman policier: introduction à la théorie et à l'histoire d'un genre littéraire. Liège: Éditions du CEFAL.

Mardones W. (2015). Los desafíos del policial etnológico. In: B. Leal. , Blanca de negro. $1^{\text {st }}$. edition. Santiago de Chile: Espora, pp. 7-.

Martín, A. (2013). Sociedad negra. Barcelona: RBA Libros.

Ponce, N. (2013). Diagonales del género. ${ }^{\text {nd }}$. edition. San Luis Potosí: El Colegio de San Luis Potosí.

Ponce, N. (2013). Autochtones et récits policiers en Amérique Hispanique . Amerika, (on line), number 8. Available at: http://amerika.revues.org/3914).

Ponce, N. (2016). El lado bestia de la vida (El asesinato de Néstor Kirchner). Santiago de Chile: Espora.

Ravelo, A. (2013). La estrategia del pequinés. Barcelona: Alrevés. 
Reuter, Y. (1989). Le roman policier et ses personnages. Vincennes: Presser Universitaires de Vincennes.

Ricœur, P. (2000). La mémoire, l'histoire, l'oubli. Paris: Gallimard.

Schweighaeuser, J.-P. (2004), Le roman noir français. Paris: Presses Universitaires de France.

Sepúlveda, L. (1999). Hot-line. Madrid: Ediciones B.

Staszak, J.-F. (2008). Qu'est-ce que l'exotisme. Le Globe, Revue genevoise de géographie (on line), Tome 148. Available in https://www.unige.ch/sciencessociete/geo/files/4314/4464/7645/Globe2008_Article1_.pdf $\quad$ (Accessed 20 $0^{\text {th }}$ November 2016).

Taibo II, P. I., Subcomandante Marcos (2005). Muertos incómodos. México D. F.: Joaquín Mortiz.

Taibo II. P. I. (1999). Primavera pospuesta. Una vision personal de México en los 90. México: Joaquín Mortiz.

Véraldi, Gabriel (1983). Le roman d'espionnage. Paris: Presses Universitaires de France.

Waleis, R. La huella del crimen (1877). Buenos Aires: Imprenta y Librerías de Mayo.

Zéraffa, M. (1971). Roman et société. Paris: Presses Universitaires de France.



